\section{Wear Tolerance of Kentucky Bluegrass and Creeping Bentgrass Following Nitrogen and Potassium Application}

\author{
Mark J. Carroll \\ Department of Agronomy, University of Maryland, College Park \\ MD 20742
}

\section{A. Martin Petrovic \\ Department of Floriculture and Ornamental Horticulture, Cornell University, Ithaca, NY 14853}

Additional index words. Poa pratensis, Agrostis palustris, healing potential, recuperative potential, wear resistance

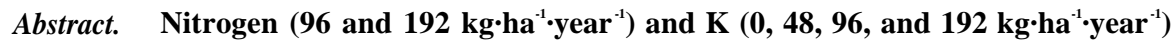
were applied in factorial combination over 4 years to two creeping bentgrass (Agrostis palustris Huds.) and one Kentucky bluegrass (Poa pratensis L.) field plot locations. Turfgrass wear tolerance and recovery from wear were evaluated in the 3rd and 4th years of $N$ and $K$ application by visually estimating the percentage of unworn turf present at the wheel track of a wear simulator or by determining the fresh weight of turfgrass tissue collected from cores removed within, and outside the simulator wheel track. Increasing the supply of $\mathrm{N}$ improved creeping bentgrass wear tolerance in the 4th year, but had no effect on Kentucky bluegrass wear tolerance. Nitrogen did not influence recovery from the wear of either species over 8 to 14 days of evaluation following the imposition of wear. Potassium did not affect the wear tolerance or recovery from wear injury in either species.
\end{abstract}

Turfgrass swards repeatedly subjected to high levels of foot or vehicular traffic inevitably lose quality. This reduction may be due to the indirect effects of soil compaction or to direct physical damage to leaves, stems, and crowns. The ability of turfgrasses to withstand above-ground damage from traffic has been termed turfgrass wear tolerance (Beard, 1973). It varies with species (Shearman and Beard, 1975a) and can be influenced by management practices. Greater wear tolerance has been correlated with species possessing a high percentage of sclerenchyma fibers and lignified cells (Shearman and Beard, 1975b) and for turfgrasses maintained at higher mowing heights (Youngner, 1961).

Nitrogen and potassium are the nutrients applied most heavily to turfgrass, yet little published research exists on their influence on turfgrass wear tolerance. Shearman and Beard (1975c) reported that creeping bentgrass $(\mathrm{CB})$ wear tolerance improved with increasing $\mathrm{N}$ until the supply reached $720 \mathrm{~kg}$ $\mathrm{N} / \mathrm{ha}$, at which point wear tolerance declined. Creeping bentgrass recovery from wear (healing potential) appears to follow a similar trend (Kohlmeier and Eggens, 1983). The

Received for publication 21 June 1990. We gratefully acknowledge the financial support of the New York Turfgrass Assn. and other regional turfgrass associations in New York. The cost of publishing this paper was defrayed in part by the payment of page charges. Under postal regulations, this paper therefore must be hereby marked advertisement solely to indicate this fact. effect of $\mathrm{K}$ on turfgrass wear tolerance and recovery from wear is less clear. Shearman and Beard (1975c) reported increased K suppply improves CB wear tolerance, while Hawes and Decker (1977) found that K had no effect on the healing potential of CB. Several popular articles (Shearman, 1989 Gold Trade Publ., 1989) and at least one review paper (Carrow and Wiecko, 1989) have stated that maintenance of high $\mathrm{K}$ fertility will enhance turfgrass wear tolerance. The research published by Shearman and Beard (1975c), appears to be the only one that documents improved turfgrass wear tolerance with increased K. Furthermore, we found no infor-

Table 1. Month of scheduled and actual date of $\mathrm{N}$ and $\mathrm{K}$ applications at Aurora and Ithaca, N. Y., field plot locations.

\begin{tabular}{|c|c|c|c|c|}
\hline \multirow[b]{3}{*}{ Year } & \multirow{3}{*}{$\begin{array}{l}\text { Scheduled } \\
\text { application }\end{array}$} & \multicolumn{3}{|c|}{ Actual application date } \\
\hline & & \multicolumn{3}{|c|}{ Location, species ${ }^{z}$} \\
\hline & & Ithaca KB & Ithaca CB & Aurora CB \\
\hline \multirow[t]{2}{*}{1983} & August & 12 Aug. & 6 Aug. & 19 Aug. \\
\hline & November & 23 Nov. & 24 Nov. & None \\
\hline \multirow[t]{4}{*}{1984} & May & 23 May & 1 June & 25 May \\
\hline & June & 27 June & 27 June & 29 June \\
\hline & August & 6 Aug. & 4 Aug. & 10 Aug. \\
\hline & November & 18 Nov. & 18 Nov. & 23 Nov. \\
\hline \multirow[t]{4}{*}{1985} & May & 8 May & 10 May & 17 May \\
\hline & June & 7 June & 18 June & 8 June \\
\hline & August & 19 Aug. & 17 Aug. & 31 Aug. \\
\hline & November & $10 \mathrm{Dec}$. & $12 \mathrm{Dec}$. & 12 Dec. \\
\hline \multirow[t]{3}{*}{1986} & May & 2 June & 6 June & 2 June \\
\hline & June & 5 July & 3 July & 5 July \\
\hline & August & 6 Sept. & None & $6 \mathrm{Sept}$. \\
\hline
\end{tabular}

${ }^{\mathrm{z}} \mathrm{KB}=$ Kentucky bluegrass, $\mathrm{CB}=$ creeping bentgrass.

${ }^{y}$ Single date application rate for either $\mathrm{N}$ or $\mathrm{K}$ was $48 \mathrm{~kg} \cdot \mathrm{ha}^{-1}$. mation relating the influence of $\mathrm{N}$ and $\mathrm{K}$ to turfgrass wear tolerance for species other than CB. We initiated tests to better establish the relationship between $\mathrm{N}$ and $\mathrm{K}$ fertilization and turfgrass wear tolerance.

In Aug. 1983 three upstate New York field plot sites were established to examine the influence of $\mathrm{N}$ and $\mathrm{K}$ on turfgrass wear tolerance and recovery from wear. Two sites were located at the Cornell Univ. Turfgrass Field Research Laboratory in Ithaca and the other on a practice green at the Wells College golf course in Aurora. The two Ithaca plot sites were a 4-year-old research puttinggreen containing single adjacent strips of 'prominent', 'Penncross', 'Seaside', and 'Penneagle' CB, and a 3-year-old stand of 'A34' Kentucky bluegrass (KB). The practice green in Aurora was seeded with 'Seaside' CB in the late 1920s. All sites had sandy loam soil texture. The KB and Aurora sites were free of thatch while the Ithaca $\mathrm{CB}$ site contained a thatch layer 8 to $15 \mathrm{~mm}$ thick. The Aurora site was mowed at $8 \mathrm{~mm}$ and the Ithaca $\mathrm{CB}$ site at $16 \mathrm{~mm}$ three to five times per week. The KB site was mowed weekly at $45 \mathrm{~mm}$. All sites were watered to prevent wilting. Before the study, the Ithaca putting green received $24 \mathrm{~kg} \mathrm{~N} / \mathrm{ha}$ from urea on 20 May, 4 and 29 June, and 29 July 1983, while the Aurora green received $75 \mathrm{~kg} \mathrm{~N} / \mathrm{ha}$ as sulfur-coated urea on 2 June and 7 July 1983. The KB site received $48 \mathrm{~kg} \mathrm{~N} / \mathrm{ha}$ from urea on 23 May 1983. The spurway acetic acid extractable P and K levels (Spurway and Lawton, 1949) determined before initiation of this study were 0.2 and 10.0, 1.1 and 5.8, and 0.1 and $5.0 \mathrm{mg} \cdot \mathrm{kg}^{-1}$, at the Ithaca $\mathrm{KB}$, $\mathrm{CB}$, and Aurora sites, respectively. These test results indicate soil $\mathrm{P}$ and $\mathrm{K}$ levels were low to very low at all three sites.

Fertility treatments were arranged in factorial combination in a randomized complete block with two rates of $\mathrm{N}$ and four rates of $\mathrm{K}$. Urea $\mathrm{N}$ was applied at $48 \mathrm{~kg} \mathrm{~N} / \mathrm{ha}$, two or four times per year and fertilizer grade $\mathrm{KCl}$ applied at $48 \mathrm{~kg} \mathrm{~K} / \mathrm{ha}$ zero, one, two, or four times per year. The single $\mathrm{K}$ application was scheduled for June, while the $\mathrm{N}$ and $\mathrm{K}$ treatments applied two and four times 
Table 2. Average percent of unworn Kentucky bluegrass and creeping bentgrass in tire track of wear simulator following the imposition of wear.

\begin{tabular}{|c|c|c|c|c|c|c|c|}
\hline \multirow{2}{*}{\multicolumn{2}{|c|}{$\begin{array}{c}\text { Element } \\
\left(\mathrm{kg} \cdot h \mathrm{a}^{-1} \cdot \mathrm{yr}^{-1}\right)\end{array}$}} & \multicolumn{6}{|c|}{ Unworn turf $(\%)^{2}$} \\
\hline & & \multicolumn{3}{|c|}{1985} & \multicolumn{3}{|c|}{1986} \\
\hline $\mathrm{N}$ & $\mathrm{K}$ & $\mathrm{KB}$ & ICB & $\mathrm{ACB}$ & $\mathrm{KB}^{\mathrm{y}}$ & ICB & $\mathrm{ACB}$ \\
\hline $\begin{array}{r}96 \\
192\end{array}$ & & $\begin{array}{l}68 \\
63\end{array}$ & $\begin{array}{l}72 \\
72\end{array}$ & $\begin{array}{l}57 \\
55\end{array}$ & $\begin{array}{l}82 \\
86\end{array}$ & $\begin{array}{l}69 \\
75\end{array}$ & $\begin{array}{l}58 \\
75\end{array}$ \\
\hline & $\begin{array}{r}0 \\
48 \\
96 \\
192\end{array}$ & $\begin{array}{l}69 \\
63 \\
67 \\
64\end{array}$ & $\begin{array}{l}72 \\
69 \\
73 \\
73\end{array}$ & $\begin{array}{l}60 \\
51 \\
57 \\
55\end{array}$ & $\begin{array}{l}86 \\
82 \\
79 \\
89\end{array}$ & $\begin{array}{l}73 \\
72 \\
73 \\
70\end{array}$ & $\begin{array}{l}63 \\
65 \\
71 \\
66\end{array}$ \\
\hline $\begin{array}{r}96 \\
96 \\
96 \\
96 \\
192 \\
192 \\
192 \\
192\end{array}$ & $\begin{array}{r}0 \\
48 \\
96 \\
192 \\
0 \\
48 \\
96 \\
192\end{array}$ & $\begin{array}{l}69 \\
66 \\
71 \\
67 \\
69 \\
60 \\
63 \\
60\end{array}$ & $\begin{array}{l}70 \\
72 \\
73 \\
71 \\
74 \\
66 \\
72 \\
75\end{array}$ & $\begin{array}{l}62 \\
53 \\
59 \\
53 \\
58 \\
50 \\
56 \\
57\end{array}$ & $\begin{array}{l}86 \\
78 \\
74 \\
88 \\
86 \\
86 \\
83 \\
90\end{array}$ & $\begin{array}{l}71 \\
69 \\
69 \\
67 \\
75 \\
75 \\
76 \\
73\end{array}$ & $\begin{array}{l}53 \\
54 \\
65 \\
59 \\
73 \\
77 \\
78 \\
72\end{array}$ \\
\hline \multicolumn{8}{|c|}{ Statistical significance } \\
\hline $\mathrm{K}$ & & $\begin{array}{l}\text { NS } \\
\text { nS }\end{array}$ & $\begin{array}{l}\text { nS } \\
\text { nS }\end{array}$ & NS & $\begin{array}{l}\text { NS } \\
\text { NS }\end{array}$ & NS & NS \\
\hline $\begin{array}{l}\mathrm{N} \times \\
\text { Time }\end{array}$ & & $\begin{array}{l}\text { NS } \\
* *\end{array}$ & $\begin{array}{l}\text { NS } \\
* *\end{array}$ & $\begin{array}{l}\text { NS } \\
* *\end{array}$ & NS & $\begin{array}{l}\text { NS } \\
* *\end{array}$ & $\begin{array}{l}\text { NS } \\
* *\end{array}$ \\
\hline$T \times$ & & NS & NS & NS & & NS & NS \\
\hline$T \times$ & & NS & NS & NS & & NS & NS \\
\hline$T(N$ & & NS & NS & NS & & NS & NS \\
\hline Evalu & (no.) & 3 & 4 & 4 & 1 & 3 & 3 \\
\hline
\end{tabular}

${ }^{2} \mathrm{~KB}, \mathrm{ICB}$, and $\mathrm{ACB}$ represent Ithaca Kentucky bluegrass, Ithaca creeping bentgrass, and Aurora creeping bentgrass sites, respectively.

y Percent of unworn turf for $1986 \mathrm{~KB}$ based on turf clippings collected from cores 2 days after wear. All other data based on visual evaluations made over 8 to 15 days following wear.

Ns, ** Nonsignificant or significant at $P=0.01$.

per year were scheduled for June and November, and May, June, August, and November, respectively. All plots received superphosphate equivalent to $96 \mathrm{~kg}$ P/ha per year in August. The scheduled and actual treatment application dates for each site are presented in Table 1. Unanticipated early snow cover precluded application of the November $\mathrm{N}$ and $\mathrm{K}$ at the Aurora site in 1983. Each treatment combination was replicated three times at the Aurora site and four times at the two Ithaca sites.

Wear was imposed in the 3rd and 4th years of the study using a gasoline-engine-driven pneumatic tire wear simulator similar to the one described by Shearman et al. (1974). The tire had a smooth surface, was $254 \mathrm{~mm}$ in diameter, $203 \mathrm{~mm}$ wide, and was mounted to the end of a $1.1-\mathrm{m}$ metal frame that was attached to a center stand post. The tire revolved around the center post at $0.49 \mathrm{~m} \cdot \mathrm{s}^{-1}$ (4.3 rpm), imparting a static tire pressure of $23 \mathrm{kPa}$ to the turf with each revolution. The center stand was placed at the intersection of four plots, which created a one-fourth revolution circular wear track within each plot. The simulator center stand was positioned at different plot intersections each year to avoid imposing wear on the same sections of turf. Wear was imposed by allowing the tire to complete 200 and 300 revolutions over the $\mathrm{CB}$ and $\mathrm{KB}$ plots, respectively. Wear-damaged foliage became a light yellow to dark brown over 2 to 4 days following the imposition of wear. The portion of undamaged or unworn turf was determined visually by estimating the percentage of turf within the wheel track that remained the same color as the turf immediately outside the wheel track. Visual ratings began 2 to 4 days after the imposition of wear and continued at 2- to 4day intervals for 8 to 14 days. The percentage of unworn turf within the tire track of each plot was estimated by two people at the two Ithaca sites and by one person at the Aurora site. Wear was applied at the Aurora site 15 Aug. 1985 and 10 Oct. 1986; at the Ithaca CB site 26 July 1985 and 20 Aug. 1986; and at the KB site on 29 July 1985 and 5 Aug. 1986. For the later KB date, wear tolerance was evaluated by collecting three 100-mm-diameter cores from within and immediately outside the wear simulator tire track on 7 Aug. The cores were sheared at the soil surface and the fresh weight of vegetative material collected was determined. The percentage of unworn turf within the wheel track was estimated by dividing the amount of material collected within the tire track by the amount collected outside the track and multiplying the quotient by 100 .

Statistical analysis. Repeated measures analysis of variance (ANOVA) (Rowell and Walters, 1976) was used to evaluate treatment effects over time. ANOVA tables were constructed for all data except $1985 \mathrm{~KB}$ by generating "type 1" sums of squares using the general linear model (GLM) procedure of SAS (SAS Institute, Inc., 1982). Inadvertent vehicular damage to two $\mathrm{KB}$ corner plots required that these plots be dropped from consideration in 1985. The ANOVA table for the $1985 \mathrm{~KB}$ data was constructed using GLM "type 4" sums of squares. The $1986 \mathrm{~KB}$ data consisted of measurements collected on a single date so that it was not necessary to use repeated measures procedures to evaluate these data. A single replicate of each N-K treatment combination was included within each of the individual cultivar strips at the Ithaca CB site. However, because there was only a single strip (i.e., replicate) of each $\mathrm{CB}$ cultivar, treatment effects among the individual CB cultivars could not be statistically assessed. All treatments having an F-test ratio probability value $<0.05$ were considered statistically significant.

Nitrogen. CB wear tolerance was the same at both sites and for both rates of $\mathrm{N}$ in 1985 (Table 2). In contrast, CB wear tolerance was significantly higher under the higher $\mathrm{N}$ regime at both sites in 1986 . In both years percentage of unworn turf increased with each successive evaluation date. Lack of a significant $\mathrm{N} \times$ time interaction at both sites for both years indicated that $\mathrm{N}$ supply had little influence on $\mathrm{CB}$ recovery from wear over the duration of the evaluation period. These findings are not in agreement with those reported by Hawes and Decker (1977) or Kohlmeier and Eggens (1983), who found that increasing the supply of $\mathrm{N}$ from 75 to 150 or from 150 to $300 \mathrm{~kg} \cdot \mathrm{ha}^{-1} \cdot$ year $^{-1}$, respectively, increased the healing potential of CB. The difference in findings between our work and the other reports is likely due to the means by which healing potential was evaluated. In the two earlier studies, healing potential was determined by visually estimating stolon regrowth over bare soil. The bare surface was created by either placing golf course cup cutter soil cores into their respective soil core holes with sod side facing the bottom of the hole (Hawes and Decker, 1977), or by removing the core and filling the void with soil from adjacent bare ground (Kohlmeier and Eggens, 1983). Determining healing potential by observing stolon regrowth over bare ground does not consider the regrowth of partially damaged stolons or the effect of existing damaged turf on stolon growth. We believe our technique of visually estimating the regrowth of the actual turfgrass area subjected to wear more accurately reflects the healing potential of $\mathrm{CB}$.

The high rate of $\mathrm{N}$ improved $\mathrm{CB}$ wear tolerance more at Aurora than at Ithaca. The difference between sites could be attributed to the date when wear was applied. At Ithaca, wear was applied 48 days after all plots had received $\mathrm{N}$, while at Aurora wear was applied 34 days after the high $\mathrm{N}$ plots were fertilized. The difference in the Ithaca $\mathrm{N}$ treatment means is representative of the cumulative effect of yearly $\mathrm{N}$ application rates, while the Aurora means reflect the effect of more recent $\mathrm{N}$ applications on wear tolerance. The 1985 and 1986 Ithaca CB data indicate that the effect of yearly $\mathrm{N}$ amount on wear increased with time. The Ithaca CB data suggest 3 years of $\mathrm{N}$ application were' needed before differences in soil $\mathrm{N}$ between the two $\mathrm{N}$ treatments became large enough to affect $\mathrm{CB}$ growth. In contrast to $\mathrm{CB}, \mathrm{KB}$ wear tolerance or recovery from wear was unaffected by $\mathrm{N}$ application.

Potassium. Neither KB nor CB bentgrass wear tolerance was influenced by $\mathrm{K}$ fertil- 
ization. In addition, $\mathrm{K}$ did not alter the rate of recovery from wear damage of either species. According to Beard (1973), high K levels increase turfgrass wear tolerance by reducing tissue succulence and increasing leaf turgidity. The $\mathrm{N}$ rates used in this study did not appear to cause lush succulent growth of either species, which may account for the nonsignificant $\mathrm{K}$ response. While it would be beneficial to document the effect of $\mathrm{K}$ on turfgrass wear tolerance at higher yearly $\mathrm{N}$ rates, the current trend in turfgrass management, based on environmental concerns, is to reduce the amount of $\mathrm{N}$ applied each year and to use slow-release forms of $\mathrm{N}$ that will not promote succulent turfgrass growth (Petrovic, 1990). Under such cultural regimes, it appears that maintaining a high yearly supply of $\mathrm{K}$ will have little influence on turfgrass wear tolerance.

\section{Literature Cited}

Beard, J.B. 1973. Turfgrass science and culture. Prentice-Hall, Englewood Cliffs, N.J.

Carrow, R.N. and G. Wiecko. 1989. Soil compaction and wear stresses on turfgrasses: Future research directions. In: H. Takatoh (ed.). Proc. 6th Intl. Turfgrass Res. Conf. Tokyo. 31 July5 Aug. 1989. Jpn. Soc. Turfgrass Sci. and Intl. Turfgrass Soc., Tokyo.

Gold Trade Publications, Inc. 1989. Fall renovation. SportsTurf 5(8):28-30, 32-33,

Hawes, D.T. and A.M. Decker. 1977. Healing potential of creeping bentgrass as affected by nitrogen and soil temperature. Agron. J. 69:212214.

Kohlmeier, G.P. and J.L. Eggens. 1983. The influence of wear and nitrogen on creeping bentgrass growth. Can. J. Plant Sci. 63:189-193.

Petrovic, A.M. 1990. The fate of nitrogenous fertilizers applied to turfgrass. J. Environ. Qual 19:1-14.

Rowell, J.G. and D.E. Walters. 1976. Analyzing data with repeated observations on each experimental unit. J. Agr. Sci. 87:423-432.

SAS Institute Inc., 1982. SAS user's guide: Statistics. SAS Institute Inc., Cary, N.C.

Shearman, R.C. 1989. Improving wear tolerance of sports turf. Grounds Maint. 24(2):84-106.

Shearman, R.C. and J.B. Beard. 1975a. Turfgrass wear tolerance mechanisms: I. Wear tolerance of seven turfgrass species and quantitative methods for determining turfgrass wear injury. Agron. J. 67:208-211.

Shearman, R.C. and J.B. Beard. 1975b. Turfgrass wear tolerance mechanisms: III. Physiological, morphological, and anatomical characteristics associated with turfgrass wear tolerance. Agron. J. 67:215-218

Shearman, R.C. and J.B. Beard. 1975c. Influence of nitrogen and potassium on turfgrass wear tolerance. Agron. Abstr. p. 101.

Shearman, R.C., J.B. Beard, C.M. Hansen, and R. Apaclla. 1974. Turfgrass wear simulator for small plot investigations. Agron. J. 66:332-334.

Spurway, C.H. and K. Lawton. 1949. Soil testing. Michigan Agr. Expt, Sta. Bul. 132.

Youngner, V,B. 1961. Accelerated wear tests on turfgrasses. Agron. J. 53:217-218. 